\title{
Analisis Implementasi Kebijakan E-Procurement Dalam Pengadaan Barang/Jasa Pada Pemerintah Kota Kotamobagu
}

\section{RAHFAN MOKOGINTA ${ }^{1}$, HERMAN KARAMOY ${ }^{2}$, HENDRIK MANOSSOH ${ }^{3}$}

\author{
${ }^{1,2,3}$ Program Magister Akuntansi Fakultas Ekonomi dan Bisnis Universitas Sam Ratulangi \\ email: mokogintarahfan@gmail.com ${ }^{1}$,hkaramoy@yahoo.com ${ }^{2}$,hendrik_manossoh@yahoo.com ${ }^{3}$
}

\begin{abstract}
Presidential Regulation No. 54/2010 regarding Procurement of Government Goods/Services has indicated that procurement of goods/services is done electronically or e-procurement (electronic procurement). E-Procurement is the procurement of goods/services carried out by using information technology and electronic transactions in accordance with the provisions of legislation. E-procurement is conducted by 2 (two) ways: electronic tendering (e-tendering) and electronic purchasing (e-purchasing). This study is aimed to analyze the implementation of e-tendering policy in the procurement of goods/services, the factors that impede the implementation of e-tendering policy and efforts made to overcome obstacles that hinder the implementation of e-tendering policy in the procurement of goods/services at Kotamobagu City Government. This is a qualitative exploratory research. The data were obtained by in-depth interviews, observation, and documentation study. The informant choice was determined purposively to obtain accurate information. Data were analyzed by data reduction, data presentation and conclusion. Data were validated by credibility (internal validity) and dependability (reliability) tests. The results show that the implementation of e-tendering policy in the procurement of goods/services in Kotamobagu City Government has been implemented by applying the principles of efficiency, effectiveness, transparency, openness, fairness/non-discriminatory and accountability. However, it does not guarantee in creating optimal competition. Constraints faced in implementing e-tendering policies are supporting infrastructure, multiple positions, application systems, supervision and delays in the General Plan of Procurement and Procurement Implementation Plan (as required document to complete the etendering process). Efforts are made to overcome these obstacles is the proposal and improvement of infrastructure, making system applications, regulation, internal control, and coordination.
\end{abstract}

Keywords: e-procurement, e-tendering, procurement, goods and services

Abstrak. Peraturan Presiden Nomor 54 Tahun 2010 tentang Pengadaan Barang/Jasa Pemerintah menekankan bahwa pengadaan barang/jasa dilakukan secara elektronik atau e-procurement (elektronic procurement). EProcurement adalah pengadaan barang/jasa yang dilaksanakan dengan menggunakan teknologi informasi dan transaksi elektronik sesuai dengan ketentuan perundang-undangan. E-procurement dilakukan dengan 2 (dua) cara yaitu electronic tendering (e-tendering) dan electronic purchasing (e-purchasing). Penelitian ini bertujuan untuk menganalisis implementasi kebijakan e-tendering dalam pengadaan barang/jasa, faktor-faktor yang menghambat implementasi kebijakan e-tendering serta upaya yang dilakukan untuk mengatasi kendala yang menghambat implementasi kebijakan e-tendering dalam pengadaan barang/jasa pada Pemerintah Kota Kotamobagu. Penelitian ini menggunakan metode kualitatif dengan pendekatan eksploratori. Data diperoleh melalui teknik wawancara mendalam, pengamatan, dan studi dokumentasi. Informan ditentukan secara purposive untuk mendapatkan hasil informasi yang tepat dan akurat. Teknik analisis data menggunakan reduksi data, penyajian data dan kesimpulan. Uji keabsahan data dalam penelitian ini meliputi uji credibility (validitas internal) dan dependability (reliabilitas). Hasil penelitian menunjukkan bahwa implementasi kebijakan $e$ tendering dalam pengadaan barang/jasa pada Pemerintah Kota Kotamobagu telah diimplementasikan dengan menerapkan prinsip efisien, efektif, transparan, terbuka, adil/tidak dikriminatif, dan akuntabel, namun belum menjamin adanya persaingan sehat secara optimal. Kendala yang dihadapi dalam implementasi kebijakan $e$ tendering ialah infrastruktur penunjang, adanya rangkap jabatan, sistem aplikasi, pengawasan dan keterlambatan Rencana Umum Pengadaan dan Rencana Pelaksanaan Pengadaan (sebagai kelengkapan berkas untuk proses $e$ tendering). Upaya yang dilakukan untuk mengatasi kendala tersebut ialah usulan dan perbaikan infrastruktur, pembuatan sistem aplikasi, regulasi, pengawasan intern, dan koordinasi.

Kata Kunci : e-procurement, e-tendering, pengadaan, barang dan jasa

\section{Pendahuluan}

Reformasi di bidang pengadaan barang/jasa bertujuan untuk menciptakan tata pemerintahan yang baik dan bersih (good governance and clean government). Tata pemerintahan yang baik dan bersih adalah seluruh aspek yang terkait dengan kontrol dan pengawasan terhadap kekuasaan yang dimiliki pemerintah dalam menjalankan fungsinya. Untuk melaksanakan prinsip good governance and clean government pemerintah harus melaksanakan prinsip akuntabilitas dan pengelolaan sumber daya 
secara efisien, mewujudkannya dengan tindakan dan peraturan yang baik dan tidak berpihak serta menjamin terjadinya interaksi ekonomi dan sosial antara stakeholders secara adil, transparan, profesional dan akuntabel.

Salah satu bentuk penyelenggaraan e-government untuk mencapai good governance ialah melalui electronic procurement (e-procurement) atau pengadaan barang/jasa pemerintah secara elektronik. Hal tersebut merupakan wujud dari perubahan yang dilakukan karena banyaknya permasalahan yang terjadi dalam proses pengadaan barang/jasa pemerintah secara konvensional. Sehubungan dengan pengadaan barang/jasa, pemerintah menerbitkan Peraturan Presiden Nomor 54 Tahun 2010 Tentang Pengadaan Barang/Jasa Pemerintah yang telah mengalami empat kali perubahan. Perubahan terakhir melalui Peraturan Presiden Nomor 4 Tahun 2015 tentang Perubahan Keempat Atas Peraturan Presiden Nomor 54 Tahun 2010. Pengertian pengadaan barang/jasa berdasarkan Peraturan Presiden Nomor 54 Tahun 2010 adalah kegiatan untuk memperoleh barang/jasa oleh Kementerian/Lembaga/Satuan Kerja Perangkat Daerah/Institusi lainnya yang prosesnya dimulai dari perencanaan kebutuhan sampai diselesaikannya seluruh kegiatan untuk memperoleh barang/jasa. Dalam Peraturan Presiden Nomor 54 Tahun 2010 tersebut telah diamanatkan agar proses pengadaan barang/jasa dilakukan secara elektronik.

E-procurement memiliki fungsi utama untuk menjamin proses pengadaan barang/jasa pemerintah sesuai dengan prosedur dan ketentuan yang berlaku. Selain itu, e-procurement juga menjamin tranparansi, standarisasi dan akuntabilitas proses pengadaan dan diawasi secara bersamasama oleh masyarakat. Hal terpenting bahwa e-procurement secara khusus atau pengadaan barang/jasa pemerintah secara umum, harus berpihak pada peningkatan kualitas pelayanan publik, tata kelola pemerintahan yang baik dan kesejahteraan rakyat yang digadang-gadang dalam konsep good governance (Ramli, 2013:11).

E-procurement adalah pengadaan barang/jasa yang dilaksanakan dengan menggunakan teknologi informasi dan transaksi elektronik sesuai dengan ketentuan perundang-undangan. $E$ procurement dilakukan dengan 2 (dua) cara yaitu electronic tendering (e-tendering) dan electronic purchasing (e-purchasing). E-tendering atau tender secara elektronik adalah tata cara pemilihan Penyedia barang/jasa yang dilakukan secara terbuka dan dapat diikuti oleh semua Penyedia barang/jasa yang terdaftar pada sistem pengadaan secara elektronik dengan cara menyampaikan 1 (satu) kali penawaran dalam waktu yang telah ditentukan. E-purchasing atau pembelian secara elektronik adalah tata cara pembelian barang/jasa melalui sistem katalog elektronik.

Penerapan e-procurement diharapkan dapat mewujudkan efisiensi dan efektivitas proses pengadaan. Hal ini akan tercapai apabila proses pengadaan barang/jasa berlangsung secara transparan dan diikuti oleh sejumlah peserta pengadaan yang cukup banyak serta mengedepankan proses persaingan yang sehat (Mayang, 2014:18).

Dalam implementasinya, proses pengadaan barang/jasa tidak jarang menimbulkan permasalahan. Data dari KPK (Komisi Pemberantasan Korupsi) melalui laporan tahunan tahun 2016 menunjukkan bahwa sejak kurun tahun 2004 sampai 2016 KPK telah menangani tindak pidana korupsi sebanyak 206 kasus, dengan kategori: pengadaan barang/jasa 148 kasus (71.8\%), pungutan 21 kasus (10.2\%), ijin 20 kasus (9.7\%), dan TPPU (Tindak Pidana Pencucian Uang) 17 kasus (8.3\%). Dari data tersebut menunjukan bahwa kasus yang terkait dengan pengadaan barang/jasa merupakan peringkat pertama yang ditangani oleh KPK.

Sama halnya dengan KPK, KPPU (Komisi Pengawas Persaingan Usaha) juga merilis data melalui laporan tahunan. Berdasarkan laporan tahunan tahun 2013-2016, jumlah laporan sebanyak 436 kasus dengan 303 kasus (69.5\%) terkait tender pengadaan barang/jasa. Data tersebut menunjukkan bahwa kondisi aktual pengadaan barang/jasa pemerintah masih belum efektif, efisien dan akuntabel.

Berdasarkan Laporan Hasil Pemeriksaan Badan Pemeriksa Keuangan Republik Indonesia atas Laporan Keuangan Pemerintah Daerah Kota Kotamobagu Tahun 2016 didapatkan beberapa temuan yang terkait dengan proses pengadaan barang/jasa. Hasil pemeriksaan tersebut antara lain adanya keterlambatan penyelesaian pekerjaan pada Dinas PUPR (Pekerjaan Umum dan Perumahan Rakyat) dan UPTD (Unit Pelaksana Teknis Daerah) Rumah Sakit Umum Daerah Kota Kotamobagu.

Pemerintah Kota Kotamobagu telah menerapkan e-tendering sejak tahun 2012. Berdasarkan data yang diperoleh dari Bagian Pengadaan Barang dan Jasa Kota Kotamobagu, jumlah paket beserta nilainya yang dilelang secara elektronik dalam kurun waktu tiga tahun terakhir adalah sebagai berikut: tahun 2014, 102 paket dengan nilai Rp108.900.820.073,00 dari total APBD sebesar Rp561.726.908.336,00 atau 19.4\% dari total APBD; tahun 2015, 93 paket dengan nilai 
Rp110.734.233.160,00 dari total APBD sebesar Rp636.579.717.000,00 atau 17.4\% dari total APBD; dan tahun 2016, 102 paket dengan nilai Rp204.633.704.870,00 dari total APBD sebesar Rp689.888.765.083,00 atau 29.7\% dari total APBD.

Berdasarkan data tersebut dapat dilihat bahwa dalam kurun waktu 3 (tiga) tahun terakhir (tahun anggaran 2014-2016) jumlah APBD Kota Kotamobagu yang dilelang menggunakan $e$ tendering sebesar $22.5 \%$. Besarnya jumlah anggaran tersebut jika pengelolaanya tidak dilakukan secara baik dan benar maka akan berpotensi menyebabkan tidak efektifnya penerapan e-tendering dalam proses pengadaan barang/jasa di lingkungan Pemerintah Kota Kotamobagu.

Dalam menganalisis implementasi kebijakan e-procurement, peneliti menentukan fokus penelitian pada sistem e-tendering tanpa melakukan analisis terhadap sistem e-purchasing. Adanya keterbatasan waktu dan dana untuk melakukan penelitian menyebabkan peneliti tidak bisa melakukan analisis terhadap pelaksanaan $e$-purchasing.

Berdasarkan uraian tersebut, penelitian ini dilakukan dengan tujuan: 1) untuk menganalisis implementasi kebijakan e-tendering dalam pengadaan barang/jasa pada Pemerintah Kota Kotamobagu; 2) untuk menganalisis kendala yang menghambat implementasi kebijakan e-tendering dalam pengadaan barang/jasa pada Pemerintah Kota Kotamobagu; dan 3) untuk menganalisis upaya yang dilakukan guna mengatasi kendala yang menghambat implementasi kebijakan e-tendering dalam pengadaan barang/jasa pada Pemerintah Kota Kotamobagu.

\section{Kerangka Konseptual Penelitian}

Mengacu pada latar belakang dan rumusan masalah serta teori yang ada, maka kerangka koseptual dalam penelitian diuraikan seperti pada gambar berikut:

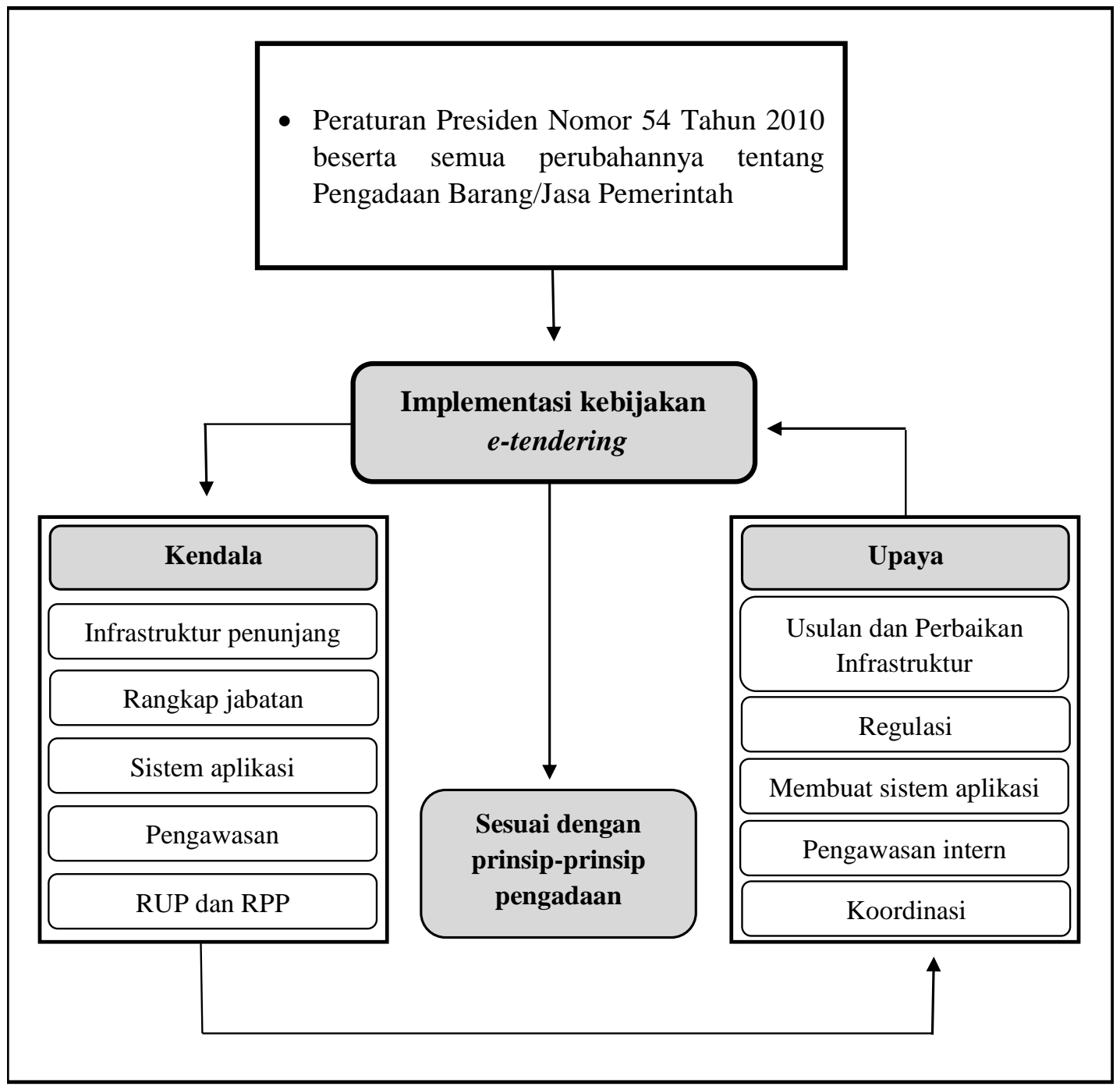




\section{Metode Penelitian}

Dalam penelitian ini, peneliti menggunakan metode penelitian kualitatif dengan pendekatan eksploratori agar data yang diperoleh akan lebih lengkap, lebih mendalam, kredibel dan bermakna. Selain itu, penelitian ini bisa menemukan lebih jauh dan mendalam terhadap kemungkinankemungkinan lain dari fenomena yang diteliti yang terkait dengan implementasi kebijakan $e$-tendering dalam pengadaan barang/jasa pada Pemerintah Kota Kotamobagu. Menurut Sugiyono (2016:8) metode penelitian kualitatif sering disebut metode penelitian naturalistic karena penelitiannya dilakukan pada kondisi yang alamiah (natural setting). Sementara itu menurut Ibrahim (2015:53), pendekatan kualitatif adalah mekanisme kerja penelitian yang berpedoman penilaian subjektif nonstatistik atau nonmatematis, dimana ukuran nilai yang digunakan dalam penelitian ini bukanlah angka-angka atau skor, melainkan kategorisasi nilai atau kualitasnya. Secara hasil, pendekatan kualitatif memberikan panduan yang sangat spesifik dan rinci terhadap hasil penelitian, ia bersifat subjektif dan trasferability. Karenanya tidak mungkin adanya generalisasi dalam penelitian kualitatif. Pendekatan eksploratori dalam penelitian kualitatif adalah cara kerja penelitian yang diamksudkan untuk menemukan lebih jauh dan mendalam terhadap kemungkinan-kemungkinan lain dari permasalahan yang diteliti. Dengan metode ekploratori, penelitian tidak lagi sekadar menggambarkan atau melukiskan atau menjelaskan seperti apa adanya realitas yang dikaji sebagaimana pada metode deskriptif. Namun tidak juga melalui tahapan uji coba sebagaimana pada metode eksperimen (Ibrahim, 2015:61).

Teknik pengumpulan data dilakukan melalui wawancara mendalam (indepth interviews), pengamatan/observasi (observation), dan dokumentasi (documentation). Selanjutnya, dilakukan uji keabsahan data dengan menggunakan uji credibility dan dependability. Wawancara dilakukan terhdadap 14 (empat belas) orang informan kunci yang terdiri dari Kepala Dinas PUPR, Kepala Dinas Informasi dan Komunikasi, 1 (satu) orang PPK (Pejabat Pembuat Komitmen) di Dinas PUPR, 1 (satu) orang PPK di UPTD Rumah Sakit Umum Daerah Kota Kotamobagu, Kepala Bagian Pengadaan Barang Dan Jasa, 4 (empat) orang anggota Pokja (Kelompok Kerja), 2 (dua) orang Auditor pada Inspektorat Daerah Kota Kotamobagu, Admin LPSE dan 2 (dua) Direktur Perusahaan sebagai Penyedia.

Teknik analisis data menggunakan analisis model interaktif menururt Miles \& Huberman yang terdiri dari tiga komponen analisis yaitu reduksi data, penyajian data serta penarikan kesimpulan dan verifikasi (Sugiyono, 2016:247). Analisis data dilakukan dengan cara: 1) Membuat transkrip wawancara (interviews transcriptions); 2) melakukan analisis data; dan 3) mengambil kesimpulan dari hasil penelitian.

\section{Analisis dan Pembahasan}

Penelitian ini dilakukan selama \pm 3 (tiga) bulan terhitung sejak Agustus sampai dengan November 2017. Peneliti melakukan wawancara kepada Informan kunci yang sudah ditentukan berdasarkan kriteri dengan menggunakan metode purposive sampling. Untuk merekam hasil wawancara digunakan audio recorder. Selain itu, peneliti menggunakan instrumen pendukung berupa buku catatan, laptop dan kamera untuk mendokumentasikan kegiatan di lapangan. Hasil rekaman wawancara kemudian dinarasikan dalam bentuk transkrip dengan menggunakan laptop dan disajikan dalam tabel. Berdasarkan hasil transkrip wawancara tersebut kemudian dilakukan organisasi data yaitu kategorisasi dan coding berdasarkan tema pokok yang disesuaikan dengan rumusan masalah.

\section{Implementasi Kebijakan E-Tendering Dalam Pengadaan Barang/Jasa Pada Pemerintah Kota Kotamobagu}

\section{Efisien}

Implementasi kebijakan e-tendering dalam pengadaan barang/jasa pada Pemerintah Kota Kotamobagu telah dilaksananakan dengan menerapkan prinsip efisien. Definisi efisien adalah perbandingan antara sasaran yang ditetapkan (output) dengan input yang digunakan. Untuk mempermudah operasionalisasi, efisien dapat diartikan sebagai usaha untuk mendapatkan output secara maksimal dengan menggunakan input tertentu atau mendapatkan output tertentu dengan menggunakan input yang minimal. Input merupakan semua biaya maupun pengorbanan sumber daya yang harus dikeluarkan dalam rangka mendapatkan output (Lembaga Kebijakan Pengadaan Barang/Jasa Pemerintah, 2016:28). 
Mardiasmo (2009:132) menyatakan bahwa proses kegiatan operasional dapat dikatakan efisien apabila suatu produk atau hasil kerja tertentu dapat dicapai dengan penggunaan sumber daya dan dana yang serendah-rendahnya (spending well). Menurut Mahmudi (2016:84), suatu organisasi, program atau kegiatan dikatakan efisien apabila mampu menghasilkan output tertentu dengan input serendah-rendahnya, atau dengan input tertentu mampu menghasilkan ouput sebesar-besarnya (spending well). Prinsip efisien sebagaimana dijelaskan dalam Peraturan Presiden Nomor 54 Tahun 2010 berarti bahwa pengadaan barang/jasa harus diusahakan dengan menggunakan dana dan daya yang minimum untuk mencapai kualitas dan sasaran waktu yang ditetapkan atau menggunakan dana yang telah ditetapkan untuk mencapai hasil dan sasaran dengan kualitas yang maksimum.

Wujud good governance menurut Mulyadi (2016:135) adalah penyelenggaraan pemerintahan Negara yang solid, bertanggung jawab, efektif dan efisien, dengan menjaga kesinergian interaksi yang konstruktif diantara domain Negara, sektor swasta dan masyarakat. Mardiasmo (2009:18) menyatakan bahwa karakteristik good governance menurut UNDP (United Nation Development Programe) salah satunya adalah efficiency dan effectiviness, yaitu pengelolaan sumber daya publik dilakukan secara berdaya guna (efisien) dan berhasil guna (efektif).

\section{Efektif}

Implementasi kebijakan e-tendering dalam pengadaan barang/jasa pada Pemerintah Kota Kotamobagu telah dilaksananakan dengan menerapkan prinsip efektif. Menurut LKPP dalam modul "Materi Pelatihan Keahlian Dasar Pengadaan Barang/Jasa" (2016:13), Transparansi Internasional mendefinisikan transpransi sebagai sebuah karakteristik dari pemerintahan, perusahaan, organisasi dan individu-individu yang terbuka, dalam arti mengungkap secara informasi, aturan, rencana, proses, dan tindakan yang dilakukan.

Sementara itu, Mulyadi (2016:133) menyatakan bahwa seluruh proses pemerintah, lembagalembaga dan informasi perlu dapat diakses oleh pihak-pihak yang berkepentingan, dan informasi yang tersedia harus memadai agar dapat dimengerti dan dipantau. Peraturan Presiden Nomor 54 Tahun 2010 tentang Pengadaan Barang/Jasa Pemerintah Pasal 5 huruf b menyatakan efektif berarti pengadaan barang/jasa harus sesuai dengan kebutuhan dan sasaran yang telah ditetapkan serta memberikan manfaat yang sebesar-besarnya.

\section{Transparan}

Implementasi kebijakan e-tendering dalam pengadaan barang/jasa pada Pemerintah Kota Kotamobagu telah dilaksananakan dengan menerapkan prinsip transparan. Menurut LKPP dalam modul "Materi Pelatihan Keahlian Dasar Pengadaan Barang/Jasa" (2016:13), Transparansi Internasional mendefinisikan transpransi sebagai sebuah karakteristik dari pemerintahan, perusahaan, organisasi dan individu-individu yang terbuka, dalam arti mengungkap secara informasi, aturan, rencana, proses dan tindakan yang dilakukan. Sementara itu, Mulyadi (2016:133) menyatakan bahwa seluruh proses pemerintah, lembaga-lembaga dan informasi perlu dapat diakses oleh pihak-pihak yang berkepentingan, dan informasi yang tersedia harus memadai agar dapat dimengerti dan dipantau. Peraturan Presiden Nomor 54 Tahun 2010 tentang Pengadaan Barang/Jasa Pemerintah Pasal 5 huruf c menyatakan bahwa, transparan berarti semua ketentuan dan informasi mengenai pengadaan barang/jasa bersifat jelas dapat diketahui secara luas oleh penyedia barang/jasa yang berminat serta oleh masyarakat pada umumnya.

\section{Terbuka}

Implementasi kebijakan e-tendering dalam pengadaan barang/jasa pada Pemerintah Kota Kotamobagu telah dilaksananakan dengan menerapkan prinsip terbuka. Prinsip terbuka dalam pengadaan barang dan jasa mempunyai makna bahwa: (a) Semua calon penyedia yang memenuhi persyaratan tertentu seperti kompetensi, kemampuan usaha, maupun persyaratan lain yang diatur dalam ketentuan yang berlaku dapat mengikuti proses tender; (b) Pejabat yang berwenang dalam pengadaan harus memberi kesempatan yang sama bagi semua calon penyedia untuk mengikuti proses pengadaan dengan tidak menambah persyaratan yang tidak obyektif yang dilakukan cenderung untuk membatasi calon penyedia tertentu tanpa alasan atau dasar peraturan perundang-undangan yang dapat dipertanggungjawabkan; (c) Dalam pengadaan barang dan jasa pemerintah, semua penyedia nasional yang berasal dari Sabang sampai Merauke, apapun suku, agama serta pilihan politiknya mempunyai hak yang sama untuk mengikuti proses pengadaan dapat ditetapkan sebagai penyedia barang/jasa yang terpilih selama memenuhi kriteria yang ditetapkan secara obyektif (LKPP, 2016:33). Salah satu prinsip dalam pengadaan barang/jasa dalam ketentuan Pasal 5 Peraturan Presiden Nomor 54 Tahun 2010 tentang Pengadaan Barang/Jasa Pemerintah adalah terbuka, yang berarti bahwa pengadaan barang/jasa 
dapat diikuti oleh semua penyedia barang/jasa yang memenuhi persyaratan/kriteria tertentu berdasarkan ketentuan dan prosedur yang jelas.

\section{Bersaing}

Implementasi kebijakan e-tendering dalam pengadaan barang/jasa pada Pemerintah Kota Kotamobagu belum menjamin adanya persaingan sehat secara optimal. Walaupun sudah menggunakan sistem elektronik namun tidak menutup adanya peluang intervensi dari pihak-pihak yang terkait yang menimbulkan potesni terjadinya persaingan tidak sehat. Definisi kompetisi menurut kamus Oxford merupakan aktivitas atau kondisi berjuang untuk mendapatkan atau memenangkan sesuatu dengan mengalahkan atau menunjukkan superioritas atas pihak lain. Persaingan hanya terjadi diantara dua pihak atau lebih yang mempunyai tujuan yang sama (LKPP, 2016:18).

Berdasarkan Peraturan Presiden Nomor 54 Tahun 2010 Pasal 5 huruf e, bersaing berarti pengadaan barang/jasa harus dilakukan melalui persaingan yang sehat diantara sebanyak mungkin penyedia barang/jasa yang setara dan memenuhi persyaratan, sehingga dapat diperoleh barang/jasa yang ditawarkan secara kompetitif dan tidak ada intervensi yang mengganggu terciptanya mekanisme pasar dalam pengadaan barang/jasa. Dengan pelaksanaan e-tendering, maka diharapkan akan terjadi persaingan yang sehat dalam pengadaan barang/jasa pada Pemerintah Kota Kotamobagu.

\section{Adil/Tidak Diskriminatif}

Implementasi kebijakan e-tendering dalam pengadaan barang/jasa pada Pemerintah Kota Kotamobagu telah dilaksananakan dengan menerapkan prinsip adil/tidak diskriminatif. Adil dan tidak diskriminatif merupakan prinsip untuk memberikan perlakuan yang sama bagi semua calon penyedia barang/jasa dan tidak mengarah untuk memberi keuntungan kepada pihak tertentu, dengan tetap memperhatikan kepentingan nasional. Tujuan prinsip ini adalah untuk memastikan bahwa dana publik tidak digunakan untuk memberikan bantuan kepada individu atau perusahaan tertentu (LKPP, 2016:23)

Berdasarkan Peraturan Presiden Nomor 54 Tahun 2010 Pasal 5 huruf f, adil/tidak diskriminatif berarti memberikan perlakuan yang sama bagi semua calon penyedia barang/jasa dan tidak mengarah untuk memberi keuntungan kepada pihak tertentu, dengan tetap memperhatikan kepentingan nasional. Prinsip adil/tidak diskriminatif telah dirasakan dampaknya pada pengadaan barang/jasa di Kota Kotamobagu dengan pelaksanaan e-tendering, karena tidak ada lagi perlakuan tertentu yang menguntungkan salah satu pihak penyedia barang/jasa.

\section{Akuntabel}

Implementasi kebijakan e-tendering dalam pengadaan barang/jasa pada Pemerintah Kota Kotamobagu telah dilaksananakan dengan menerapkan prinsip akuntabel. Akuntabilitas menurut Sedarmayanti (2011:410) adalah kewajiban individu/penguasa yang dipercayakan mengelola sumber daya dan yang bersangkutan dengannya untuk menjawab hal yang menyangkut pertanggungjawaban fiskal, manajerial dan program. Menurut Romzek dan Ingraham (Sangkala, 2012:3), akuntabilitas diartikan sebagai sebuah kondisi dasar yang dapat memberikan jawaban atas pertanyaan seseorang terhadap hasil kinerja yang diharapkan.

Akuntabilitas dalam pengadaan publik berarti bahwa siapapun yang terlibat dalam proses pengadaan bertanggung jawab atas tindakan dan keputusan yang diambil sehubungan dengan proses pengadaan publik. Pejabat yang terlibat dalam pengadaan berkewajiban menjelaskan dan mempertanggungjawabkan hasil dan konsekuensi dari tindakan, produk, keputusan dan kebijakan termasuk administrasi, tata kelola dan pelaksanaan dalam lingkup peran atau jabatannya (LKPP, 2016:35). Peraturan Presiden Nomor 54 Tahun 2010 Pasal 5 Huruf g menyatakan bahwa akuntabel berarti harus sesuai dengan aturan dan ketentuan yang terkait dengan pengadaan barang/jasa sehingga dapat dipertanggungjawabkan.

\section{Kendala yang Menghambat Implementasi Kebijakan E-Tendering Dalam Pengadaan Barang/Jasa Pada Pemerintah Kota Kotamobagu \\ 1. Infrastruktur Penunjang}

Salah satu kendala yang dirasakan menghambat pelaksanaan e-tendering dalam proses pengadaan barang/jasa pada Pemerintah Kota Kotamobagu ialah infrastruktur penunjang yaitu keterbatasan ruangan dan masalah kapasitas jaringan internet. Menurut Mulyadi (2016:188), pelayanan publik diartikan sebagai pemberian layanan (melayani) keperluan orang atau masyarakat yang mempunyai kepentingan pada organisasi itu sesuai aturan pokok dan tata cara yang telah ditetapkan. Mahmudi (2016:219) menyatakan bahwa pelayanan publik adalah segala kegiatan 
pelayanan yang dilaksanakan oleh penyelenggara pelayanan publik sebagai upaya pemenuhan kebutuhan publik dan pelaksanaan ketentuan perundang-undangan. Sedangkan pengertian pelayanan publik menurut Undang-Undang Nomor 25 Tahun 2009 ialah kegiatan atau rangkaian kegiatan dalam rangka pemenuhan kebutuhan pelayanan sesuai dengan peraturan perundang-undangan bagi setiap warga Negara dan penduduk atas barang, jasa dan/atau pelayanan administratif yang disediakan oleh penyelenggara pelayanan publik.

Menurut Mahmudi (2016:224), instansi penyedia pelayanan publik dalam memberikan pelayanan harus memperhatikan prinsip-prinsip pelayanan publik, yang diantaranya adalah kelengkapan sarana dan prasarana, kemudahan akses dan kenyamanan. Pelaksanaan e-tendering pada Pemerintah Kota Kotamobagu terkendala pada fasilitas kantor yang belum representatif berupa adanya keterbatasan ruangan kantor dan kendala jaringan internet.

\section{Rangkap Jabatan}

Adanya rangkap jabatan merupakan faktor penghambat dari sisi Sumber Daya Manusia (SDM) dalam implementasi kebijakan e-tendering pada Pemerintah Kota Kotamobagu, dimana 12 dari 16 belas anggota Pokja statusnya masih bersifat rangkap jabatan di SKPD (Satuan Kerja Perangkat Daerah) lain. Suwatno dan Priansa (2011:16) menyatakan bahwa manajemen sumber daya manusia adalah suatu bidang manajemen yang khusus mempelajari hubungan dan peranan manusia dalam organisasi perusahaan. Menurut Nawawi (2006:305), sumber daya manusia adalah faktor sentral dilingkungan organisasi profit (perusahaan dan industry), nonprofit (instansi pemerintah), dan voluntir (organisasi/perkumpulan berdasarkan kemanusiaan dan pengabdian). Menurut Sedarmayanti (2011:144) sumber daya manusia adalah seseorang yang siap, mau dan mampu memberikan sumbangan terhadap usaha pencapaian tujuan organisasi.

Manusia sebagai sumber daya adalah penggerak organisasi. Organisasi tidak akan berfungsi tanpa manusia. Disamping itu telah dikatakan pula bahwa manusia membutuhkan organisasi dan sebaliknya organisasi membutuhkan manusia sebagai sumber daya penggerak organisasi. Oleh karena itu secara ekstrim dapat dikatakan organisasi adalah manusia, tanpa manusia tidak ada organisasi. Dengan demikian harus diterima kenyataan bahwa sumber daya manusia merupakan sumber utama atau faktor sentral di dalam sebuah organisasi apapun bentuknya (Nawawi, 2006:305).

Mulyadi (2016:26) menyatakan bahwa implementasi suatu kebijakan pada dasarnya adalah suatu perubahan atau transformasi yang bersifat multiorganisasi, dimana perubahan yang diterapkan melalui strategi implementasi kebijakan ini mengaitkan seluruh lapisan masyarakat. Salah satu variabel yang berperan penting dalam pencapaian keberhasilan implementasi menurut Dwiyanto dalam Mulyadi (2016:28) adalah sumber daya, yaitu menekankan setiap kebijakan harus didukung oleh sumber daya yang memadai, baik sumber daya manusia maupun sumber daya finansial. Sumber daya manusia adalah kecukupan baik secara kualitas maupun kuantitas implementor yang dapat melingkupi seluruh kelompok sasaran. Sumber daya finansial adalah kecukupan modal investasi atas sebuah program/kebijakan.

\section{Sistem Aplikasi}

Faktor penghambat berikutnya dalam implementasi kebijakan e-tendering dalam pengadaan barang dan jasa pada Pemerintah Kota Kotamobagu ialah belum lengkapnya fitur dalam sistem aplikasi e-tendering dalam pengiriman berkas dari PPK kepada Pokja maupun sebaliknya. UNDP mendefinisikan governance sebagai pelaksanaan kewenangan politik, ekonomi dan administrasi untuk mengelola permasalahan Negara (Sangkala, 2012:106). Bank Dunia mendefinisikan good governance sebagai pelayanan publik yang lebih efisien, sistem yang handal serta pemerintahan yang bertanggungjawab (akuntabel) kepada publik. Asas-asas good governance menurut Bank Dunia adalah transparansi, partisipasi dan akuntabilitas (Owen Podger, Maria Sumardjono, Wayan K, Tirtayasa dan Mark Turner, 2002:1)

Teknologi Informasi dan Komunikasi (TIK) merupakan salah satu teknologi yang berkembang dengan sangat pesat. Pesatnya perkembangan TIK akan membuka peluang dan tantangan untuk menciptakan (to create), mengakses (to access), mengolah (to process) dan memanfaatkan (to utilize) informasi secara tepat dan akurat. Informasi merupakan suatu komoditi yang sangat berharga di era globalisasi untuk dikuasai dalam rangka meningkatkan daya saing pelayanan suatu organisasi termasuk Pemerintah Daerah secara berkelanjutan. Untuk menjawab tantangan tersebut, Pemerintah Republik Indonesia membuat kebijakan untuk membangun electronic government for good governance yang terintegrasi muali dari tingkat pemerintahan daerah hingga ke pusat. Tujuannya 
adalah agar infrastruktur TIK yang akan dibangun dapat dimanfaatkan secara bersama untuk berkoordinasi oleh seluruh instansi, baik di pusat maupun di daerah (Mulyadi, 2016:201).

\section{Pengawasan}

Faktor penghambat implementasi kebijakan e-tendering selanjutnya ialah belum dilakukannya audit secara elektronik (e-audit) oleh Inspektorat Kota Kotamobagu. Audit adalah pengumpulan dan evaluasi bukti tentang informasi untuk menentukan dan melaporkan derajat kesesuaian antara informasi itu dan dan kriteria yang telah ditetapkan (Alvin A. Arens, Randal J. Elder dan Mark S. Beasley, 2014:1). Sementara menurut Hery (2016:10) audit didefinisikan sebagai suatu proses yang sistematis untuk memperoleh dan mengevaluasi (secara obyektif) bukti yang berhubungan dengan asersi tentang tindakan-tindakan dan kejadian ekonomi, dalam rangka menentukan tingkat kepatuhan antara asersi dengan kriteria yang telah ditetapkan, serta mengkomunikasikan hasilnya kepada pihakpihak yang berkepentingan.

Berdasarkan ketentuan dalam Peraturan Peraturan Presiden Nomor 54 Tahun 2010 Pasal 116, Kementerian/Lembaga/Institusi dan Pemerintah Provinsi/Pemerintah Kabupaten/Kota diwajibkan melakukan pengawasan terhadap PPK dan Unit Layanan Pengadaan (ULP), termasuk pengawasan mengenai pelaksanaan swakelola dan penggunaan produksi dalam negeri. Pengawasan dilakukan antara lain membuat sistem pengawasan intern atas pengadaan barang/jasa termasuk menugaskan Aparat Pengawasan Intern Pemerintah (APIP) untuk melakukan audit pengadaan barang/jasa. Ketentuan mengenai APIP diatur pula pada Pasal 1 butir 11 Peraturan Presiden Nomor 54 Tahun 2010 yang menyatakan bahwa APIP adalah aparat yang melakukan pengawasan melalui audit, reviu, evaluasi, pemantauan dan kegiatan pengawasan lain terhadap penyelenggaraan tugas dan fungsi organisasi $(\mathrm{K} / \mathrm{L} / \mathrm{D} / \mathrm{I})$.

Kedua ketentuan dalam Peraturan Presiden Nomor 54 Tahun 2010 tersebut sejalan dengan ketentuan pasal 47 dan 48 Peraturan Pemerintah Nomor 60 Tahun 2008 tentang Sistem Pengendalian Intern Pemerintah, bahwa APIP harus melakukan pengawasan intern atas penyelenggaraan tugas dan fungsi Instansi Pemerintah termasuk akuntabilitas keuangan negara. Pengawasan intern adalah seluruh proses kegiatan audit, reviu, evaluasi, pemantauan, dan kegiatan pengawasan lain terhadap penyelenggaraan tugas dan fungsi organisasi dalam rangka memberikan keyakinan yang memadai bahwa kegiatan telah dilaksanakan sesuai dengan tolok ukur yang telah ditetapkan secara efektif dan efisien untuk kepentingan pimpinan dalam mewujudkan tata pemerintahan yang baik.

Berdasarkan Peraturan Kepala Lembaga Kebijakan Pengadaan Barang/Jasa Pemerintah Nomor 1 Tahun 2015 Tentang E-Tendering, Auditor melaksakan audit melalui SPSE (Sistem Pengadaan Secara Elektronik). Pada Pasal 1 angka 5 Peraturan Kepala Lembaga Kebijakan Pengadaan Barang/Jasa Pemerintah Nomor 1 Tahun 2015 dinyatakan bahwa pengguna SPSE adalah perorangan/badan usaha yang memiliki hak akses kepada aplikasi SPSE, direpresentasikan oleh user id dan password yang diberikan oleh LPSE, antara lain Pejabat Pembuat Komitmen, Kelompok Kerja Unit Layanan Pengadaa, Penyedia barang/jasa, Auditor/Pemeriksa. Selanjutnya dalam Lampiran Peraturan Kepala Lembaga Kebijakan Pengadaan Barang/Jasa Pemerintah Nomor 1 Tahun 2015 tersebut dinyatakan bahwa Proses audit pengadaan secara elektronik dilaksanakan melalui fasilitas yang disediakan dalam aplikasi SPSE. Auditor dan/atau pemeriksa yang berwenang berdasarkan peraturan perundang-undangan untuk melakukan pemeriksaan terhadap paket pengadaan, hanya dapat mengakses informasi atau data, mengunduh (download) dan membuka file, baik yang disampaikan oleh Pokja ULP maupun peserta pemilihan paket pekerjaan yang menjadi objek audit sebagaimana tercantum dalam surat tugas.

\section{Keterlambatan Input RUP (Rencana Umum Pengadaan) dan RPP (Rencana Pelaksanaan Pengadaan)}

Kendala terakhir yang menjadi penghambat implementasi kebijakan e-tendering dalam pengadaan barang/jasa pada Pemerintah Kota Kotamobagu ialah SKPD yang terlambat melakukan input RUP dalam SiRUP serta keterlambatan pengiriman berkas RPP oleh Pejabat Pembuat Komitmen yang dibutuhkan dalam proses e-tendering. Berdasarkan Peraturan Presiden Nomor 54 Tahun 2010, salah satu tugas dan kewenangan Pengguna Anggaran sebagai ialah menetapkan dan mengumumkan secara luas RUP. RUP diumumkan melalui website KLDI (Kementerian/Lembaga/Pemerintah Daerah/ Institusi) masing-masing, papan pengumuman resmi untuk masyarakat dan Portal Pengadaan Nasional melalui LPSE. KLDI mengumumkan rencana pelaksanaan Pengadaan Barang/ Jasa yang Kontraknya akan dilaksanakan pada Tahun Anggaran berikutnya/yang akan datang. 
Setelah RUP dimasukan dalam SiRUP, kemudian PPK menetapkan rencana pelaksanaan pengadaan yang terdiri dari spesifikasi teknis barang/jasa, Harga Perkiraan Sendiri (HPS) dan Rancangan Kontrak, sebagaimana yang diatur dalam Pasal 11 Peraturan Presiden Nomor 54 Tahun 2010. Berdasarkan Peraturan Kepala Lembaga Kebijakan Pengadaan Barang/Jasa Pemerintah Nomor 1 Tahun 2015 PPK menyerahkan rencana pelaksanaan pengadaan barang/jasa yang berisikan paket, spesifikasi teknis, HPS, dan rancangan umum kontrak kepada Pokja ULP. Rencana pelaksanaan pengadaan tersebut selanjutnya diserahkan kepada Pokja untuk kemudian dilakukan proses $e$ tendering.

Salah satu ciri penting yang dimiliki oleh setiap peraturan perundang-undangan yang baik adalah kemampuannya untuk memadukan hierarki badan-badan pelaksana. Bila sistem yang diatur dalam peraturan tidak tegas, maka kemungkinan akan terjadi perbedaan-perbedaan perilaku kepatuhan yang cukup mendasar diantara pejabat-pejabat pelaksana dan kelompok-kelompok sasaran, sebab mereka akan berusaha untuk melakukan penilaian sendiri terhadap kebijakan dimaksud. Menurut Munaim (2012), diperlukan pemahaman dan kesamaan persepsi dan langkah secara integral dan menyeluruh dari semua kalangan dalam menjamin terlaksananya e-procurement yang sesuai dengan asas dan karakteristik good governance.

Konsep implementasi berasal dari bahasa Inggris yaitu to implement. Dalam kamus besar Webster yang dikutip oleh Wahab (2006:64) menjelaskan bahwa to implement (mengimplementasikan) berati to provide the means for carrying out (menyediakan sarana untuk melaksanakan sesuatu); dan to give practical effect to (untuk menimbulkan dampak/akibat terhadap sesuatu). George C. Edward III dalam Mulyadi (2016:68) mengemukakan 4 (empat) variabel yang mempengaruhi implementasi kebijakan yakni komunikasi, sumber daya, disposisi, dan struktur birokrasi.

\section{Upaya Yang Dilakukan Untuk Mengatasi Kendala Implementasi Kebijakan E-Tendering Dalam Pengadaan Barang/Jasa Pada Pemerintah Kota Kotamobagu \\ 1. Usulan dan Perbaikan Infrastruktur}

Upaya yang dilakukan oleh dalam rangka mengatasi kendala infrastrukur penunjang berupa keterbatasan ruangan ialah mengusulkan penambahan ruangan atau pemindahan kantor yang representatif, namun sampai tahun ini belum terwujud. Sementara untuk masalah jaringan internet upaya yang telah dilakukan yaitu melakukan pengadaan jaringan internet dan back up server melalui Dinas Informasi dan Komunikasi.

Infrastruktur merupakan fasilitas yang dapat menunjang keberhasilan penerapan suatu kebijakan. Fasilitas termasuk salah satu sumber daya yang berpengaruh terhadap keberhasilan impelemntasi kebijakan. Sumber daya memiliki peranan penting dalam implementasi kebijakan. Edward III dalam Widodo (2011:98) mengemukakan bahwa bagaimanapun jelas dan konsistensinya ketentuan-ketentuan dan aturan-aturan serta bagaimanapun akuratnya penyampaian ketentuanketentuan atau aturan-aturan tersebut, jika para pelaksana kebijakan yang bertanggung jawab untuk melaksanakan kebijakan kurang mempunyai sumber-sumber daya untuk melaksanakan kebijakan secara efektif maka implementasi kebijakan tersebut tidak akan efektif.

Sumber daya di sini berkaitan dengan segala sumber yang dapat digunakan untuk mendukung keberhasilan implementasi kebijakan. Sumber daya ini mencakup sumber daya manusia (staff), anggaran (budgetary), fasilitas (facility) serta informasi dan kewenangan (information and authority).

\section{Membuat Sistem Aplikasi}

Upaya yang dilakukan dalam mengatasi kendala pada sistem aplikasi yang belum lengkap untuk memfasilitasi kegiatan e-tendering yaitu dengan membuat sistem aplikasi yang dinamakan Pantau Pengadaan. Aplikasi Pantau Pengadaan diharapkan akan mempermudah pengiriman berkas secara on-line yang dibutuhkan dalam proses $e$-tendering, sehingga prosesnya tidak lagi manual dan bisa lebih cepat.

Teknologi Informasi dan Komunikasi (TIK) merupakan salah satu teknologi yang berkembang dengan sangat pesat. Pesatnya perkembangan TIK akan membuka peluang dan tantangan untuk menciptakan (to create), mengakses (to access), mengolah (to process) dan memanfaatkan (to utilize) informasi secara tepat dan akurat. Informasi merupakan suatu komoditi yang sangat berharga di era globalisasi untuk dikuasai dalam rangka meningkatkan daya saing pelayanan suatu organisasi termasuk Pemerintah Daerah secara berkelanjutan. Untuk menjawab tantangan tersebut, Pemerintah Republik Indonesia membuat kebijakan untuk membangun Electronic Government for Good 
Governance yang terintegrasi muali dari tingkat pemerintahan daerah hingga ke pusat. Tujuannya adalah agar infrastruktur TIK yang akan dibangun dapat dimanfaatkan secara bersama untuk berkoordinasi oleh seluruh instansi, baik di pusat maupun di daerah (Mulyadi, 2016:201).

\section{Regulasi}

Dalam rangka penyelenggaraan pemerintahan, Pemerintah Kota Kotamobagu menerbitkan Peraturan Daerah Nomor 8 Tahun 2016 tentang Pembentukan dan Sususan Perangkat Daerah Kota Kotamobagu. Sebagai penjabaran dari Peraturan Daerah Nomor 8 Tahun 2016 tersebut, telah diterbitkan Peraturan Walikota Nomor 30 Tahun 2016 tentang Kedudukan, Susunan Organisasi, Tugas dan Fungsi Serta Tata Kerja Sekretariat Daerah Tipe B. Dalam Peraturan Walikota Nomor 30 Tahun 2016 tersebut, kedudukan Bagian Pengadaan Barang dan Jasa berada di bawah Sekretariat Daerah Kota Kotamobagu.

Susunan Pokja Kota Kotamobagu diatur dalam dalam Keputusan Walikota Kota Kotamobagu Nomor 10 Tahun 2017 tentang Pengangkatan Kelompok Kerja Pengadaan Barang dan Jasa Pemerintah Kota Kotamobagu. Dalam Keputusan Nomor 10 Tahun 2017 tersebut, jumlah Pokja terdiri atas 2 yaitu Pokja I yang membidangi Pengadaan Barang, Jasa Konsultansi dan Jasa Lainnya serta Pokja II yang membidangi Pekerjaan Konstruksi. Anggota Pokja terdiri dari 16 orang yang masingmasing terdiri dari 7 orang Pokja I dan 9 orang Pokja II. Dari 16 orang anggota Pokja tersebut, hanya 4 orang yang merupakan pegawai tetap pada Bagian Pengadaan Barang dan Jasa sementara 12 orang lainnya masih merangkap jabatan sebagai pegawai tetap pada SKPD lainnya. Upaya Pemerintah Kota Kotamobagu dalam membentuk Bagian Pengadaan Barang dan Jasa menjadi unit organisasi mandiri di bawah Sekretariat Daerah merupakan hal yang positif. Namun, status anggota Pokja yang sebagian besar masih merangkap jabatan berpengaruh terhadap pelaksanaan $e$-tendering.

\section{Pengawasan Intern}

Pengawasan intern yang dilakukan oleh Inspektorat selaku APIP melalui pemeriksaan terhadap sistem elektronik pengadaan barang/jasa pada Pemerintah Kota Kotamobagu masih dilakukan secara manual pada proses perencanaan dan penganggaran. Arens, dkk (2014:2) menjelaskan bahwa audit adalah pengumpulan dan evaluasi bukti tentang informasi untuk menentukan dan melaporkan derajat kesesuaian antara informasi itu dan dan kriteria yang telah ditetapkan. Sementara menurut Hery (2016:10) audit didefinisikan sebagai suatu proses yang sistematis untuk memperoleh dan mengevaluasi (secara obyektif) bukti yang berhubungan dengan asersi tentang tindakan-tindakan dan kejadian ekonomi, dalam rangka menentukan tingkat kepatuhan antara asersi dengan kriteria yang telah ditetapkan, serta mengkomunikasikan hasilnya kepada pihak-pihak yang berkepentingan.

Berdasarkan ketentuan dalam pasal 116 Peraturan Peraturan Presiden Nomor 54 Tahun 2010, pengawasan dilakukan antara lain membuat sistem pengawasan intern atas pengadaan barang/jasa termasuk menugaskan Aparat Pengawasan Intern Pemerintah (APIP) untuk melakukan audit pengadaan barang/jasa. Ketentuan mengenai APIP diatur pula pada pasal 1 butir 11 Peraturan Presiden Nomor 54 Tahun 2010, bahwa APIP adalah aparat yang melakukan pengawasan melalui audit, reviu, evaluasi, pemantauan dan kegiatan pengawasan lain terhadap penyelenggaraan tugas dan fungsi organisasi $(\mathrm{K} / \mathrm{L} / \mathrm{D} / \mathrm{I})$.

\section{Koordinasi}

Upaya yang dilakukan untuk mengatasi kendala keterlambatan dalam melakukan input Rencana Umum Pengadaan secara tepat waktu dan keterlambatan pengiriman dokumen Rencana Pelaksanaan Pengadaan sebagai kelengkapan berkas untuk proses e-tendering, ialah berupa koordinasi. Bagian Layanan Pengadaan Barang dan Jasa Kota Kotamobagu melakukan Koordinasi antar SKPD agar proses input Rencana Umum Pengadaan bisa lebih cepat dan juga tidak terjadi keterlambatan pengiriman dokumen Rencana Pelaksanaan Pengadaan. Upaya ini dilakukan agar tidak ada lagi keterlambatan dalam proses e-tendering yang pada akhirnya akan berpengaruh terhadap pelaksanaan paket-paket pekerjaan di lingkungan Pemerintah Kota Kotamobagu.

Dalam sebuah organisasi setiap pimpinan perlu untuk mengkoordinasikan kegiatan kepada anggota organisasi yang diberikan dalam menyelesaikan tugas. Dengan adanya penyampaian informasi yang jelas, pengkomunikasian yang tepat, dan pembagian pekerjaan kepada para bawahan oleh manajer maka setiap individu bawahan akan mengerjakan pekerjaannya sesuai dengan wewenang yang diterima. Tanpa adanya koordinasi setiap pekerjaan dari individu karyawan maka tujuan perusahaan tidak akan tercapai. Hasibuan (2006:85) berpendapat bahwa koordinasi adalah kegiatan 
mengarahkan, mengintegrasikan, dan mengkoordinasikan unsur-unsur manajemen dan pekerjaanpekerjaan para bawahan dalam mencapai tujuan organisasi.

Koordinasi menurut Awaluddin Djamin dalam Hasibuan (2011:86) diartikan sebagai suatu usaha kerja sama antara badan, instansi, unit dalam pelaksanaan tugas-tugas tertentu, sehingga terdapat saling mengisi, saling membantu dan saling melengkapi. Dengan demikian koordinasi dalam hal perbaikan kendala jaringan internet merupakan suatu usaha oleh pemerintah yang mampu menyelaraskan pelaksanaan tugas maupun kegiatan dalam suatu organisasi pemerintahan. Koordinasi dan hubungan kerja ini saling berhubungan karena koordinasi hanya dapat tercapai sebaik-baiknya dengan melakukan hubungan kerja yang efektif. Hubungan kerja adalah bentuk administrasi yang membantu tercapainya koordinasi. Oleh karena itu dikatakan bahwa hasil akhir daripada komunikasi (hubungan kerja) adalah tercapainya koordinasi dengan cara yang berhasil guna dan berdaya guna (efektif dan efisien). Koordinasi dimaksudkan sebagai usaha menyatukan kegiatan-kegiatan dari satuan-satuan kerja (unit-unit) organisasi, sehingga organisasi bergerak sebagai kesatuan yang bulat guna melaksanakan seluruh tugas organisasi untuk mencapai tujuannya.

\section{Penutup}

Berdasarkan hasil penelitian dan pembahasan, maka kesimpulan dalam penelitian ini yaitu: implementasi kebijakan e-tendering dalam pengadaan barang/jasa pada Pemerintah Kota Kotamobagu telah diimplementasikan dengan menerapkan prinsip-prinsip efisien, efektif, transparan, terbuka, adil/tidak dikriminatif, dan akuntabel, namun belum menjamin adanya persaingan sehat secara optimal; kendala yang dihadapi dalam implementasi kebijakan e-tendering ialah infrastruktur penunjang, adanya rangkap jabatan, sistem aplikasi, pengawasan dan keterlambatan Rencana Umum Pengadaan dan Rencana Pelaksanaan Pengadaan sebagai kelengkapan berkas untuk proses $e$ tendering; dan upaya yang dilakukan untuk mengatasi kendala tersebut ialah usulan dan perbaikan infrastruktur, pembuatan sistem aplikasi, regulasi, pengawasan intern, dan koordinasi.

Berdasarkan kesimpulan atas hasil penelitian, terdapat beberapa hal yang disarankan sebagai pertimbangan untuk perbaikan dalam implementasi kebijakan e-tendering: 1) Kepada Pemerintah Kota Kotamobagu: menyediakan infrastruktur penunjang berupa ruang kerja yang memadai bagi Pokja Bagian Pengadaan Barang dan Jasa, melakukan inovasi dengan mengembangkan dan menciptakan aplikasi untuk mendukung pelaksanaan sistem e-tendering dalam pengadaan barang/jasa secara elektronik (e-procrurement), menempatkan anggota Pokja menjadi pegawai tetap pada Bagian Pengadaan Barang dan Jasa Kota Kotamobagu sehingga tidak ada lagi yang rangkap jabatan, meningkatkan peran APIP dalam pengawasan dengan melaksanakan e-audit terhadap proses pelaksanaan e-tendering dan juga menerbitkan regulasi tentang pelaksanaan probity audit terhadap proses pengadaan barang/jasa dan melaksanakan percepatan proses pengadaan barang/jasa melalui sistem e-tendering dengan melakukan input RUP setelah RKA (Rencana Kerja dan Anggaran) dibahas dan disetujui antara Pemerintah dan DPRD (Dewan Perwakilan Rakyat Daerah). Selanjutnya mempercepat pengiriman dokumen RPP kepada Pokja agar segera dilakukan proses $e$-tendering; 2) kepada kalangan akademisi: penelitian ini diharapkan dapat menambah khasanah ilmu pengetahuan dan hasil penelitian dapat menjadi bukti empirik untuk penelitian selanjutnya guna menganalisis implementasi kebijakan e-tendering dalam pengadaan barang/jasa pemerintah secara elektronik (eprocurement).

\section{Daftar Pustaka}

Arens, Alvin A. Elder, Randal J. dan Beasley, Mark S. 2014. Auditing \& Jasa Asuransi: Pendekatan Terintegrasi. Edisi Kelimabelas Jilid 1. Jakarta: Penerbit Erlangga.

Badan Pemeriksa Keuangan Republik Indonesia. 2017. Laporan Hasil Pemeriksaan Atas Laporan Keuangan Daerah Kota Kotamobagu Tahun 2016, Laporan Hasil Pemeriksaan Atas Kepatuhan Terhadap Peraturan Perundang-Undangan.

Hasibuan, Malayu S.P. 2006. Manajemen Dasar, Pengertian, dan Masalah. Edisi Revisi, Bumi Aksara: Jakarta.

2011. Manajemen Sumber Daya Manusia. Bumi Aksara. Jakarta.

Hery. 2016. Auditing dan Asurans: Pemeriksaan Akintansi Berbasis Standar Audit Internasional. Jakarta: Penerbit PT. Grasindo,

Ibrahim. 2015. Metodologi Penelitian Kualitatif; Panduan Penelitian beserta Contoh Proposal Kualitatif. Perpustakaan Nasional: Katalog dalam Terbitan. Pontianak. 
Komisi Pemberantasan Korupsi. 2017. Laporan Tahunan 2016. Jakarta.

Komisi Pengawas Persaingan Usaha. 2014. Laporan Tahunan 2013. Jakarta. 2015. Laporan Tahunan 2014. Jakarta. 2016. Laporan Tahunan 2015. Jakarta.

Lembaga Kebijakan Pengadaan Barang/Jasa Pemerintah. 2016. Materi Pelatihan Keahlian Dasar Pengadaan Barang/Jasa. Jakarta.

Mahmudi. 2016. Manajeman Kinerja Sektor Publik, Edisi Ketiga: Cetakan Pertama. Yogyakarta. Penerbit Unit Penerbit Dan Percetakan Sekolah Tinggi Ilmu Manajemen YKPN.

Mardiasmo. 2009. Akuntansi Sektor Publik. Penerbit ANDI. Yogyakarta.

Mayang, Wiwik Widyawati (2014). "MIRA-Approach" Model in Implementation of E-Procurement System Policy within Ministry of Religious Affairs in Gorontalo Province. International Journal of Business and Management Invention Volume 6 Issue 6 June 2017, hal. 8-25.

Mulyadi. 2016. Sistem Akuntansi: Jakarta: Salemba Empat.

Munaim. 2012. Kebijakan Pengelolaan Barang Milik Daerah Pada Pemerintah Provinsi Nusa Tenggara Barat. Tugas Akhir Program Magister (TAPM). Program Pasca Sarjana, Universitas Terbuka. UPNJJ Mataram.

Nawawi, Hadari. 2006. Kepemimpinan Mengefektifkan Organisasi Cetakan Kedua. Yogyakarta: Gadjah Mada University Press.

Podger, Owen. Sumardjono, Maria. Tirtayasa, Wayan K. dan Turner, Mark. 2002. Beberapa Gagasan Penyelenggaraan Otonomi Daerah di Indonesia. Balai Pustaka. Jakarta.

Ramli, Samsul. 2013. Bacaan Wajib Para Praktisi Pengadaan Barang/Jasa Pemerintah. Jakarta: Visimedia.

Republik Indonesia. Undang-Undang Nomor 25 Tahun 2009 tentang Pelayanan Publik. Jakarta. . Peraturan Pemerintah Nomor 60 Tahun 2008 tentang Sistem Pengendalian Internal Pemerintah. Jakarta. . Peraturan Presiden Nomor 54 Tahun 2010 Tentang Pengadaan Barang/Jasa Pemerintah. Jakarta. . Peraturan Presiden Nomor 4 Tahun 2015 tentang Perubahan Keempat Atas Peraturan Presiden Nomor 54 Tahun 2010 tentang Pengadaan Barang/Jasa Pemerintah. Jakarta.

Peraturan Kepala Lembaga Kebijakan Pengadaan Barang/Jasa Pemerintah Nomor 1 Tahun 2015 Tentang E-Tendering. Jakarta.

Sangkala. 2012. Dimensi-Dimensi Manajemen Publik. Penerbit Ombak. Yogyakarta.

Sedarmayanti. 2011. Membangun Dan Mengembangkan Kepemimpinan Serta Meningkatkan Kinerja Untuk Meraih Keberhasilan. Bandung. PT Refika Aditama (2-26).

Sugiyono. 2016. Metode Penelitian Kuantitatif, Kualitatif, dan R\&D. Bandung: Penerbit Alfabeta.

Suwatno dan Donni Juni Priansa. 2011. Manajemen SDM dalam Organisasi Publik dan Bisnis. Bandung: Alfabeta.

Wahab, Solichin Abdul. 2006. Analisis Kebijaksanaan, Dari Formulasi ke Implementasi Kebijakan Negara. Jakarta: PT. Bumi Aksara.

Widodo, Joko. 2011. Analisis Kebijakan Publik: Konsep dan Aplikasi Analisis Proses Kebijakan Publik. Malang: Bayumedia Publishing. 